\title{
Preferensi Dosen Pada Proses Penjadwalan Kuliah Menggunakan Algoritma Genetik Studi Kasus: Universitas Al Azhar Indonesia
}

\author{
Dody Haryadi ${ }^{1}$, Ade Jamal ${ }^{1}$ \\ ${ }^{1}$ Program Studi Teknik Informatika, Fakultas Sains dan Teknologi, Universitas Al Azhar Indonesia, \\ Jalan Sisingamangaraja, Kebayoran Baru, Jakarta Selatan, 12110
}

Penulis untuk Korespondensi/E-mail: dodyharyadi@uai.ac.id

Abstrak - Proses penjadwalan kuliah di suatu Universitas merupakan suatu proses yang memiliki peran penting. Dengan adanya sistem yang dapat melakukan penjadwalan dengan mempersingkat proses dan tidak adanya jadwal yang bentrok, kegiatan perkuliahan akan berjalan secara tertib. Penelitian ini akan membahas mengenai proses penjadwalan kuliah di Universitas Al Azhar Indonesia (UAI) dengan menggunakan algoritma genetika. Analisa kebutuhan sistem dilakukan sesuai dengan proses bisnis penjadwalan kuliah di UAI. Pada algoritma genetika ini terdapat hard constrain dan soft constrain yang bisa ditentukan sesuai dengan kebutuhan, seperti satu jadwal kuliah tidak boleh ada yang beririsan dengan jadwal kuliah yang lainnya. Sistem dapat merekam jadwal yang dapat dipenuhi dan juga tidak dapat dipenuhi dosen, sehingga ketika dalam proses penjadwalan, sistem dapat mencari waktu pengganti lainnya. Terdapat perubahan proses bisnis penjadwalan kuliah di UAI, dan juga berdampak pada pengembangan sistem informasi penjadwalan kuliah. Terdapat input dan output file json yang digunakan untuk komunikasi antara sistem informasi penjadwalan kuliah yang ada dengan sistem penjadwalan algoritma genetik.

\section{Kata Kunci-Penjadwalan Kuliah, Algoritma Evolusi, Presensi Waktu Dosen}

Abstract - The process of scheduling a lecture at a university is a process that has an important role. With a system that can perform scheduling by shortening the process and the absence of conflicting schedules, lecture activities will run in an orderly manner. This research will discuss about the process of scheduling lecture at Al Azhar University of Indonesia (UAI) by using genetic algorithm. Analysis of system requirements is done in accordance with business process scheduling lectures at UAI. In this genetic algorithm there is a hard constrain and soft constrain that can be determined according to need, such as a lecture schedule should not be any that incline with other lecture schedules. The system can record schedules that can be met and also can't be met lecturers, so that when in the process of scheduling, the system can find another replacement time. There is a change in the business process of lecture scheduling in UAI, and also has an impact on the development of lecture scheduling information system. There is an input and output json file that is used for communication between existing lecture scheduling information systems with genetic algorithm scheduling system.

Keywords - Scheduling Lectures, Evolution Algorithm, Lecturer Time Presentation

\section{PENDAHULUAN}

$\mathrm{P}$ roses penjadwalan kuliah di suatu Universitas merupakan suatu proses yang memiliki peran penting. Dengan adanya sistem yang dapat melakukan penjadwalan secara efektif dan efisen, kegiatan perkuliahan akan berjalan secara tertib tanpa adanya jadwal yang bentrok. Penelitian ini akan membahas mengenai proses penjadwalan kuliah di 
Universitas Al Azhar Indonesia (UAI) dengan menggunakan algoritma genetika.

Dalam peracangan sistem, penulis menggunakan Unifield Modeling Languague (UML), dan metode System Development Life Cycle (SDLC) dalam proses pembuatan sistem. Sedangkan bahasa pemrograman yang digunakan yaitu JAVA, HTML, PHP dan Javascript serta basis data MySQL. Pada akhirnya sistem yang dirancang dapat melakukan penjadwalan lebih cepat karena dilakukan sepenuhnya oleh sistem yang sudah menggunakan algoritma evolusi, sehingga jadwal yang dihasilkan lebih optimum. Selain itu, sistem ini dapat memenuhi proses bisnis yang belum ada pada sistem sebelumnya seperti Modul Presensi Waktu Mengajar Dosen. Modul ini merekam data jadwal yang dapat/tidak dapat dihadiri dosen untuk mengajar.

\section{KERANGKA TEORI/ TINJAUAN PUSTAKA}

\section{PENJADWALAN KULIAH}

Penjadwalan kuliah adalah kegiatan menyusun sekumpulan aktifitas perkuliahan yang diajarkan oleh pengajar tertentu dalam sumberdaya waktu (jam kuliah) dan tempat (ruang kelas) tertentu dengan memperhatikan beberapa persyaratan[1]. Masalah penjadwalan kuliah menjadi bahasan yang menarik karena dalam pencarian solusinya terdapat kombinasi dari banyak persyaratan/batasan didalamnya yang disebut hard constraint dan soft constraint. Hard constraint adalah kondisi persyaratan (batasan) yang bersifat mutlak (harus terpenuhi), dapat disebut juga persyaratan pokok[1]. Yang termasuk dalam hard constraint adalah :

1. Ruangan memiliki kapasitas tempat duduk yang terbatas.

2. Kelas kuliah memiliki ruangan yang spesifik.

3. Dosen tidak bisa mengajar pada lebih dari satu kelas kuliah pada waktu yang sama

4. Mahasiswa tidak bisa mengambil mata kuliah berbeda pada waktu yang sama.

5. Dosen memiliki preferensi waktu mengajar di mana ada waktu tertentu dosen tidak bisa mengajar.

6. Tidak boleh ada lebih dari satu event dalam waktu (hari dan jam) dan ruang yang sama.
7. Kelas kuliah yang memiliki lebih dari satu sks, harus menggunakan ruang yang sama dalam waktu yang berkelanjutan.

Sedangkan soft constraint adalah kondisi persyaratan yang diinginkan, di mana jika kondisi dipenuhi maka akan menghasilkan penjadwalan kuliah yang lebih baik [1]. Sebagai contoh yang termasuk kedalam kategori soft constraint adalah:

1. Dosen memiliki preferensi waktu mengajar (waktu di mana dosen bias mengajar, waktu yang diharapkan untuk mengajar dan waktu yang tidak diharapkan untuk mengajar).

2. Rasio perbandingan jumlah mahasiswa dengan kapasitas ruangan.

3. Ruang kelas memiliki preferensi sesuai program studi.

4. Efisiensi ruang dan waktu.

Pencarian solusi penjadwalan kuliah yang baik dan benar haruslah tidak mengabaikan salah satu atau lebih batasan masalah yang ada. Kita dapat mengatakan bahwa pencarian solusi masalah penjadwalan kuliah adalah optimasi kombinatorial. Optimasi kombinatorial adalah proses mengoptimalkan fungsi objektif dari permasalahan yang sifatnya kombinasi dengan menggunakan sumber daya yang terbatas $[1,2]$. Di mana jumlah ruangan dan slot waktu (hari dan jam) yang terbatas menjadi sumber dayanya.

Permasalahan penjadwalan kuliah seperti ruang kelas yang memiliki tempat duduk yang terbatas serta dosen dan mahasiswa yang tidak boleh bentrok dalam suatu penjadwalan kuliah, merupakan kombinasi permasalahan yang akan kita cari urutan penempatan kelasnya (solusinya). Dengan cara menjabarkan permasalahan umum tersebut kedalam multidimensional ruang dan waktu dalam satu sumber daya yang terbatas. Tidak lupa, bahwa setiap permasalahan yang ada tidak boleh diabaikan karena akan menghasikan solusi penjadwalan kuliah tidak seperti yang diinginkan.

Beberapa algoritma yang telah digunakan untuk meyelesaikan permasalahan penjadwalan kuliah [3], seperti:

1. Teknik pewarnaan graf: Pendekatan yang paling tradisional yang terbukti sangat efisien untuk ukuran masalah penjadwalan yang kecil. 
2. Teknik pencarian lokal: di mana perbaikan solusi yang lebih optimum dicari disekitar sebuah solusi yang sudah diketahui sebelumnya. Variasi pencarian lokal yang sering digunakan adalah metode simulated annealing dan tabu search.

3. Teknik optimasi berdasarkan teori evolusi: yaitu algoritma evolusi, termasuk diantaranya adalah algoritma genetika.

\section{ALGORITMA GENETIKA}

Algoritma genetika adalah teknik pencarian heuristik yang didasarkan pada gagasan evolusi seleksi alam dan genetik. Algoritma ini memanfaatkan proses seleksi alamiah yang dikenal dengan proses evolusi. Dalam proses evolusi, individu secara terus-menerus mengalami perubahan gen untuk menyesuaikan dengan lingkungan hidupnya. "Hanya individuindividu yang kuat yang mampu bertahan". Proses seleksi alamiah ini melibatkan perubahan gen yang terjadi pada individu melalui proses perkembangbiakan. Proses perkembangbiakan ini didasarkan pada analogi struktur genetik dan perilaku kromosom dalam populasi individu dengan menggunakan dasar sebagai berikut:

1. Individu dalam populasi bersaing untuk sumber daya alam dan pasangannya.

2. Mereka yang paling sukses di setiap kompetisi akan menghasilkan keturunan yang lebih baik daripada individu-individu yang berkinerja buruk.

3. Gen dari individu yang baik akan menyebar ke seluruh populasi sehingga dua orantua yang baik kadang-kadang akan menghasilkan keturunan yang lebih baik dari orangtuanya.

4. Setiap ada pergantian generasi maka generasi terbaru ini biasanya lebih cocok dengan lingkungan mereka. Dengan kata lain, generasi baru ini bias menyesuaikan dengan keadaan lingkungannya.

\section{CIRI-CIRI ALGORITMA GENETIKA}

Ciri-ciri permasalahan yang membutuhkan penyelesaian menggunakan algoritma genetika antara lain [4]:

1. Ruang pencarian sangat besar, kompleks, atau kurang dipahami.

2. Tidak ada pengetahuan yang memadai untuk menyederhanakan ruang pencarian yang sangat besar menjadi ruang pencarian yang lebih sempit.

3. Tidak ada analisis matematis yang bisa menangani ketika metode konvensional gagal menyelesaikan masalah yang dihadapi.

4. Solusi yang dihasilkan tidak harus optimal, asal sudah memenuhi kriteria sudah bisa diterima.

5. Mempunyai kemungkinan solusi yang jumlahnya tak hingga.

6. Membutuhkan solusi "real time", yaitu solusi yang bisa didapatkan dengan cepat sehingga dapat diimplementasikan untuk permasalahan yang mempunyai perubahan yang cepat.

\section{ISTILAH DALAM ALGORITMA GENETIKA}

Berikut ini beberapa pengertian dasar yang berkaitan dengan teori algoritma genetika [4]:

1. Gen (Genotype) adalah variabel dasar yang membentuk suatu kromosom. Dalam algoritma genetika, gen ini bisa bernilai biner, float, integer, maupun karakter.

2. Allele adalah nilai dari suatu gen, bisa berupa biner, float, integer, maupun karakter.

3. Kromosom adalah gabungan dari gen-gen yang membentuk arti tertentu. Ada beberapa macam bentuk kromosom, yaitu:

a. Kromosom biner, adalah kromosom yang disusun dari gen-gen yang bernilai biner.

Kromosom ini mempunyai tingkat keberhasilan yang tinggi. Jumlah gen pada kromosom biner menunjukkan tingkat ketelitian yang diharapkan. Kromosom ini bagus bila digunakan untuk permasalahan yang parameter dan range nilainya tertentu.

b. Kromosom float, adalah kromosom yang disusun dari gen-gen yang bernilai pecahan, termasuk gen yang bernilai bulat. Kromosom ini merupakan model yang jumlah parameternya banyak. Tingkat keberhasilan dari kromosom ini rendah daalam kecepatan (jumlah generasi). Model cross-over dan mutasi pada kromosom ini sangat berbeda dengan kromosom biner sehingga diperlukan strategi khusus untuk melakukan cross-over dan mutasi. Nilai range ( $\min \max$ ) menjadi tidak penting.

c. Kromosom string, yaitu kromosom yang disusun dari gen-gen yang bernilai string.

d. Kromosom kombinatioral, yaitu kromosom yang disusun dari gen-gen yang dinilai berdasarkan urutannya. 
4. Individu adalah kumpulan gen, bisa dikatakan sama dengan kromosom. Individu menyatakan salah satu kemungkinan solusi dari suatu permasalahan.

5. Populasi adalah sekumpulan individu yang akan diproses secara bersama-sama dalam satu siklus proses evolusi.

6. Generasi menyatakan satu satuan siklus proses evolusi.

7. Nilai Fitness menyatakan seberapa baik nilai dari suatu individu atau solusi yang didapatkan. Nilai inilah yang dijadikan acuan untuk mencapai nilai optimal. Algoritma genetika bertujuan untuk mencari individu yang mempunyai nilai fitness yang paling optimal (bisa maksimum atau minimum, tergantung pada kebutuhan).

\section{JSON (JavaScript Object Notation)}

JSON (JavaScript Object Notation) adalah format pertukaran data yang ringan, mudah dibaca dan ditulis oleh manusia, serta mudah diterjemahkan dan dibuat (generate) oleh komputer. Format ini dibuat berdasarkan bagian dari bahasa pemrograman JavaScript, Standar ECMA-262 Edisi ke-3 Desember 1999. JSON merupakan format teks yang tidak bergantung pada bahasa pemrograman apapun karena menggunakan gaya bahasa yang umum digunakan oleh programmer keluarga $\mathrm{C}$ termasuk C, C++, C\#, Java, JavaScript, Perl, Python, dll. Karena sifat-sifat tersebut, menjadikan JSON ideal sebagai bahasa pertukaran data [5]. JSON terbuat dari dua struktur [5]:

1. Kumpulan pasangan nama/nilai. Pada beberapa bahasa, hal ini dinyatakan sebagai objek (object), rekaman (record), struktur (structure), kamus (dictionary), tabel hash (hash table), daftar berkunci (keyed list), atau associative array.

2. Daftar nilai terurutkan (an ord ered list of values). Pada kebanyakan bahasa, hal ini dinyatakan sebagai larik (array), vektor (vector), daftar (list), atau urutan (sequence).

Struktur-struktur data ini disebut sebagai struktur data universal. Pada dasarnya, semua bahasa pemrograman modern mendukung struktur data ini dalam bentuk yang sama maupun berlainan. Hal ini pantas disebut demikian karena format data mudah dipertukarkan dengan bahasa-bahasa pemrograman yang juga berdasarkan pada struktur data ini [5].

JSON menggunakan bentuk sebagai berikut [5]:

1. Objek adalah sepasang nama/nilai yang tidak terurutkan. Objek dimulai dengan \{ (kurung kurawal buka) dan diakhiri dengan \} (kurung kurawal tutup). Setiap nama diikuti dengan: (titik dua) dan setiap pasangan nama/nilai dipisahkan oleh, (koma).

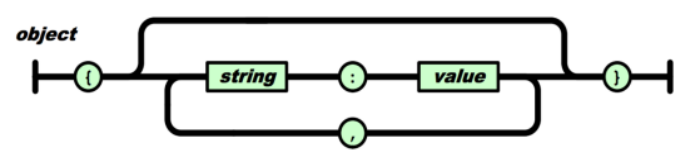

Gambar 1. Kerangka Script Objek pada JSON (Sumber: json.org)

2. Larik adalah kumpulan nilai yang terurutkan. Larik dimulai dengan [ (kurung kotak buka) dan diakhiri dengan ] (kurung kotak tutup). Setiap nilai dipisahkan oleh, (koma).

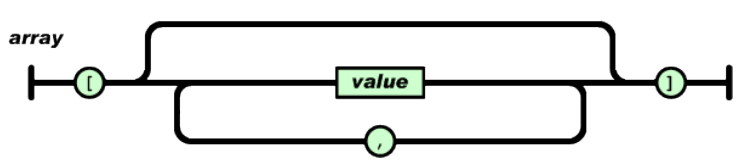

Gambar 2. Kerangka Script Array pada JSON (Sumber: json.org)

Pada poin 1 dan 2 di atas dijelaskan mengenai kerangka script objek dan array pada JSON yang disajikan dalam bentuk ekspresi diagram. Tanda panah menunjukkan urutan atribut yang digunakan dalam script JSON. Adapun ketika disajikan dalam ekpresi reguler atau yang biasa disingkat sebagai regex (Regular Expression), maka kerangka script JSON gabungan antara objek dan array adalah sebagai berikut:

"[ ". "\{ ". "string". ":" . "value". "[ ". " $\{$ ". "string". ": ". "value". "\}". "]". " \}". "]"

3. Nilai (value) dapat berupa sebuah string dalam tanda kutip ganda, atau angka, atau true atau false atau null, atau sebuah objek atau sebuah larik. Struktur- struktur tersebut dapat disusun bertingkat.

4. String adalah kumpulan dari nol atau lebih karakter Unicode, yang dibungkus dengan tanda kutip ganda. Di dalam string dapat digunakan backslash escapes "I" untuk membentuk karakter khusus. Sebuah karakter mewakili karakter tunggal pada string. String ini sangat mirip dengan string $\mathrm{C}$ atau Java. 
5. Angka adalah sangat mirip dengan angka di C atau Java, kecuali format oktal dan heksadesimal tidak digunakan.

6. Spasi kosong (whitespace) dapat disisipkan di antara pasangan tanda-tanda tersebut, kecuali beberapa detail encoding yang secara lengkap dipaparkan oleh bahasa pemrograman yang bersangkutan.

\section{METODE PENELITIAN}

Pembahasan penelitian ini menggunakan Metode Waterfall - System Development Live Cycle. Urutan kegiatan dapat dilihat pada gambar 3. Tahapan yang dilakukan yaitu Requirement Analysis, System Design, dan Implementation.

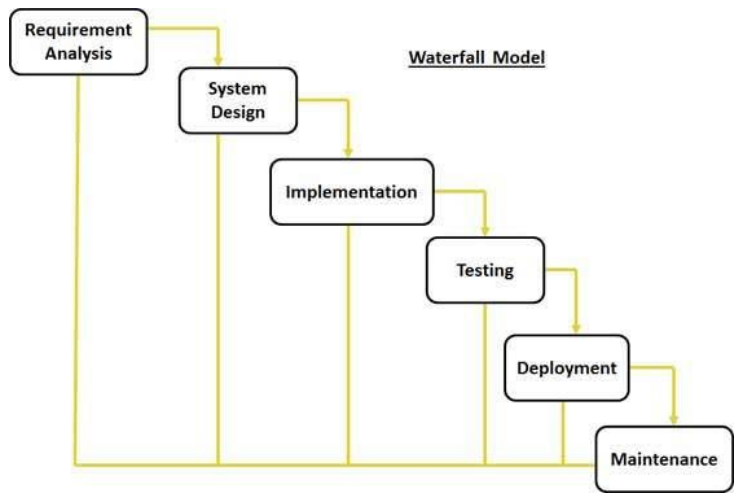

Gambar 3. Waterfall Model

(Sumber: http://www.w3ii.com)

Pada tahapan Requirement Analysis dilakukan kegiatan analisa kebutuhan pada sistem. Dilakukan observasi dan wawancara dengan unit Pusat Komputer dan Sistem Informasi (PKSI) yang bertindak sebagai pengembang sistem informasi di UAI.

Setelah itu dilakukan System Desain. Pada tahapan ini merancang sistem yang akan dibuat dalam bentuk activity diagram, dan logical relational structure.

Setelah rancangan jadi, dilakukan tahap implementation. Pada tahapan ini mengimplementasikan rancangan yang telah jadi menjadi program komputer.

\section{HASIL DAN PEMBAHASAN}

\section{Activity Diagram}

Di UAI sudah ada sistem informasi penjadwalan kuliah yang sudah digunakan. Aktivitas yang dilakukan dapat dilihat pada gambar 4. Pada setiap pertengahan semester dilakukan proses penjadwalan kuliah untuk semester berikutnya, aktivitas yang dilakukan yaitu:

1. Biro Administrasi Akademik (BAA) menjadwalkan Mata Kuliah Universitas (MKU);

2. Program Studi (Prodi) mengisi daftar Mata Kuliah (MK) yang ingin dibuka;

3. BAA memvalidasi MK yang dibuka Prodi;

4. Prodi mengisi dosen, dan jadwal kuliah;

5. BAA memvalidasi jadwal;

6. BRT melakukan plot ruang kuliah.

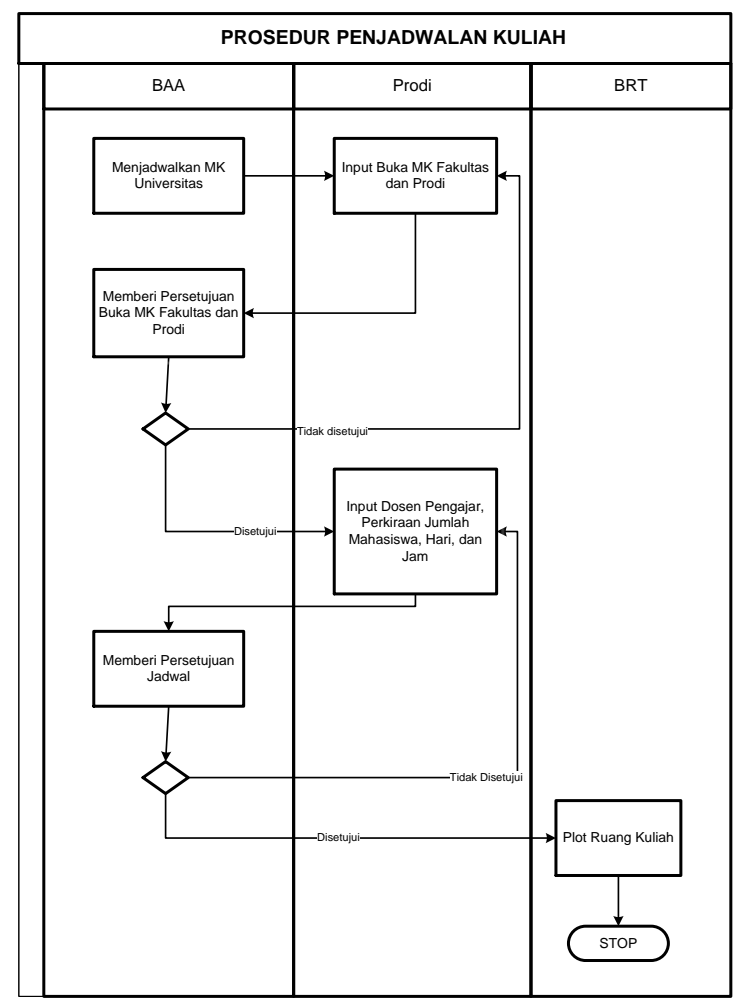

Gambar 4. Prosedur Penjadwalan Kuliah Sistem Berjalan

Hasil analisa pada penelitian ini merubah prosedur penjadwalan kuliah yang sudah ada. Aktivitas dapat dilihat pada gambar 5 . 


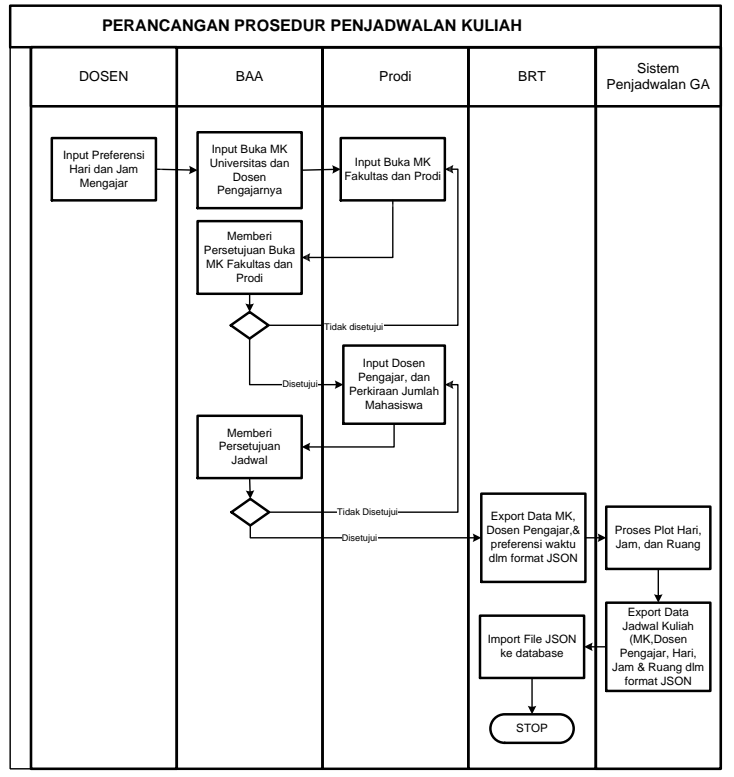

Gambar 5. Prosedur Penjadwalan Kuliah HASIL ANALISA

Aktivitas penjadwalan kuliah yang dilakukan yaitu sebagai berikut:

1. Dosen mengisi daftar hari dan jam yang memungkinkan bagi dosen tersebut untuk mengajar di semester depan.

2. BAA dan Prodi memasukkan daftar MK yang dibuka beserta dosen pengajar.

3. MK yang dibuka prodi divalidasi oleh BAA.

4. BRT melalui sistem mengeksport data jadwal mengajar, file dalam format json.

5. Program penjadwalan mencari hari, jam, dan ruang yang tersedia untuk jadwal yang dibuka. Proses ini menghasilkan file jadwal yang sudah dilengkapi ruang dalam format json.

6. BRT melalui sistem mengimport data jadwal.

\section{Logical Relational Structure}

Rancangan basis data yang diguakan pada sistem ini dapat dilihat pada gambar 6 . Rancangan basis data ini diimplementasi ke dalam basis data MySQL.

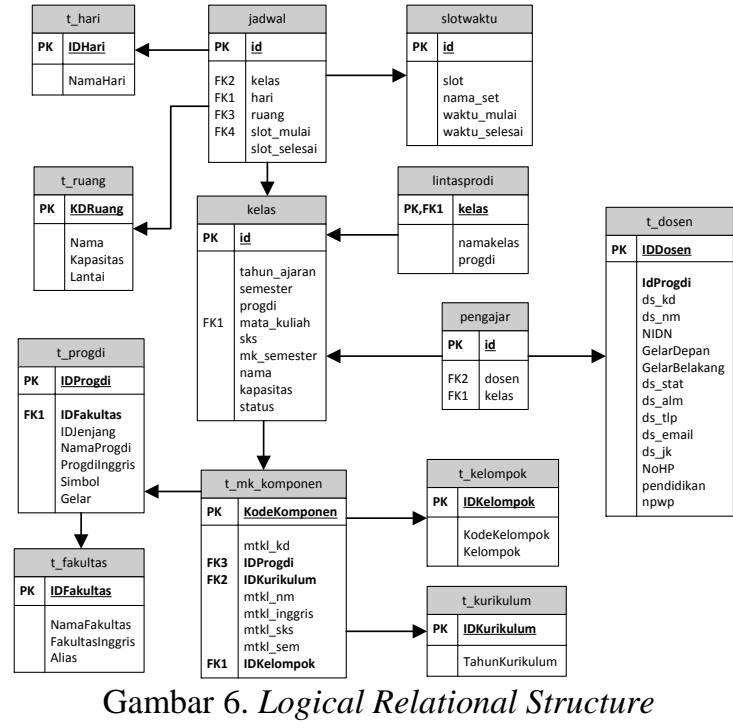

\section{Perancangan Antar Muka}

Terdapat 4 (empat) antar muka yang dibuat, dijelaskan di bawah ini.

\section{Perancangan Tampilan Buka Mata Kuliah}

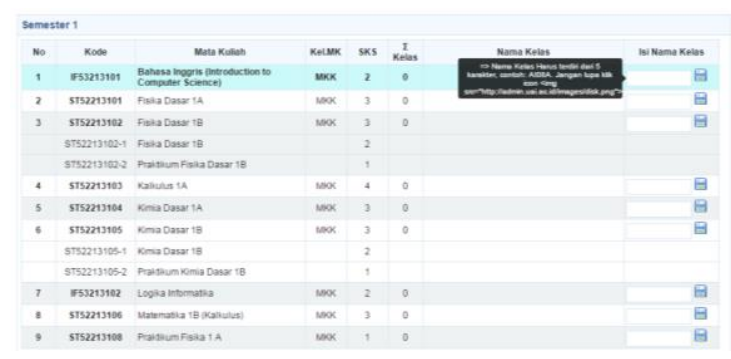

Perancangan Tampilan Plotting Dosen, Perkiraan Mahasiswa, dan Lintas Program Studi

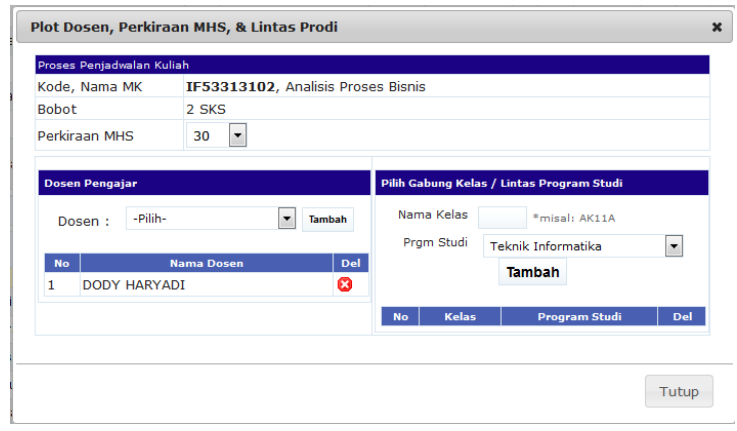

Perancangan Tampilan Plot Hari, Jam, dan Ruang Kuliah 


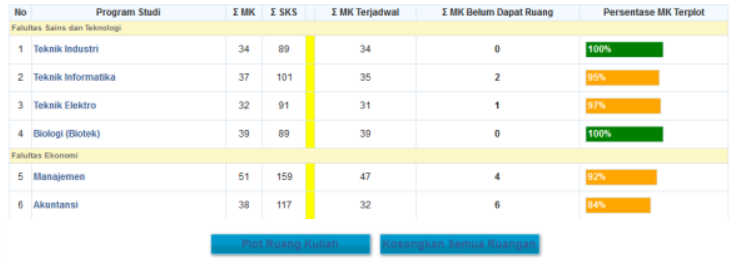

Perancangan Tampilan Laporan Jadwal Kuliah

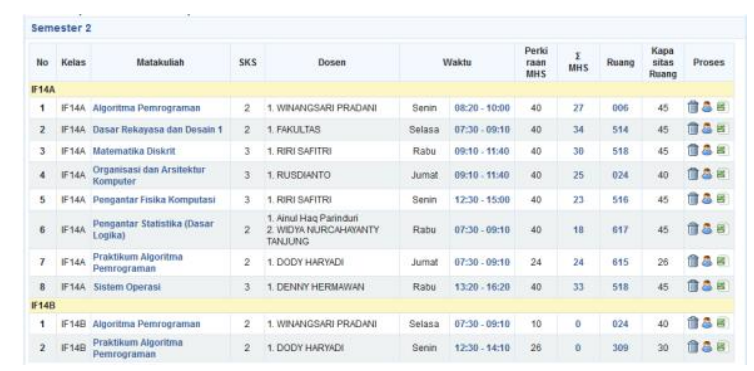

\section{KESIMPULAN}

Kesimpulan dari penelitian ini yaitu:

1. Dengan adanya preferensi jadwal mengajar dosen yang diisi sebelum proses penjadwalan dimulai, sistem dapat memiliki alternatif jadwal mengajar dosen jika terjadi bentrok.

2. Proses penjadwalan kuliah mengalami perubahan proses bisnis. Yang awalnya data dosen, hari, dan jam mengajar harus diisi, jadi hanya memerlukan data dosen.

\section{UCAPAN TERIMA KASIH}

Penulis mengucapkan terima kasih kepada LP2M UAI yang telah mendanai penelitian ini. Dan juga unit PKSI yang telah memberikan informasi proses bisnis penjadwalan kuliah, dan akses ke struktur basis data.

\section{DAFTAR PUSTAKA}

[1] Abramson, D. (1991) Constructing School Timetables using Simulated Annealing: Parallel and Sequential Solutions", Management Science, Vol. 37, No. 1, January, 1991, 98-113

[2] Al-Betar M.A., Khader A.T. and Gani T.A. (2008) A Harmony Search Algorithm for University Course Timetabling. In: Burke E., Gendreau M. (eds.). The Proceedings of the 7th International Conference on the Practice and Theory of Automated Timetabling, Montréal, Canada, 2008.

[3] Burke, E.K., Elliman, D.G. and Weare, R.F. (1994) A Genetic Algorithm based University Timetabling System, In Proceedings of the 2nd East-West International Conference on Computer Technologies in Education, Sept, 1994, Crimea, Ukraine, 35-40.

[4] Frausto-Solís, J., Alonso-Pecina, F. (2008) A Hybrid Simulated Annealing-Tabu Search Algorithm for Post Enrollment Course Timetabling, in Proceeding of the 7th International Conference on the Practice and Theory of Automated Timetabling PATAT '08, Edmund K Burke and Michel Gendreau (eds), August 2008

[5] Json Org. (n.d.). Pengenalan Json. http://www.json.org/json-id.html. Diakses pada Februari 2015.

[6] Jamal, A. (2010) University Course Scheduling using the Evolutionary Algorithm , (submitted paper to International Conference on Soft Computing, Intelligent System and Information Technology, Bali, Indonesia, July 2010

[7] Lewis, R. and Paechter, B. (2005) Application of the Grouping Genetic Algorithm to University Course Timetabling, In G. Raidl and J. Gottlieb (eds) Evolutionary Computation in Combinatorial Optimization, Berlin Germany, Springer LNCS 3448, pages 144-153

[8] Utami, A., and Jamal, A. (2014) Aplikasi Optimasi Penjadualan Kuliah dengan Algoritma Genetika, FST UAI - Teknik Informatika, Juli 2014

[9] Alfi, Muhammad Dhafin, Jamal, A, and Haryadi, Dody (2014) Perancangan Aplikasi Preferensi Waktu Mengajar Dosen Berbasis Web dengan Output Json File sebagai input pada Aplikasi Optimalisasi Penjadwalan Kuliah, FST UAI - Teknik Informatika, Januari 2014 